Copyright (C) 2015 by Academic Publishing House Researcher

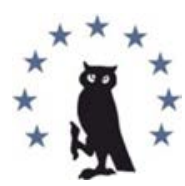

Published in the Russian Federation

European Researcher

Has been issued since 2010.

ISSN 2219-8229

E-ISSN 2224-0136

Vol. 94, Is. 5, pp. 403-412, 2015

DOI: $10.13187 /$ er.2015.94.403

www.erjournal.ru

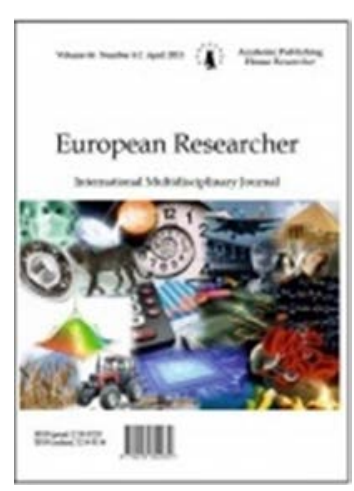

Art History

Искусствоведение

UDC 292.09: 94(470)

\title{
"The war is Already in Progress, and I Still here ..." or a Picture of Everyday Military rear Life Through the eyes of the Contemporary Theater
}

\author{
Vera K. Krylova \\ Institute of the Humanities and the Indigenous Peoples of the North of the Siberian Branch of the \\ Russian Academy of Sciences, Russian Federation \\ 677027, Yakutsk, Petrovskogo, 1 \\ $\mathrm{PhD}$ in Art Study, expert on the theater, Senior Researcher \\ E-mail: kvkrepressgur@mail.ru
}

\begin{abstract}
The article analyzes the performance "The Life and Extraordinary Adventures of Private Ivan Chonkin" on the novel by Vladimir Voinovich, staged by Academic Russian Drama Theatre in Yakutia. This performance is not only about Chonkin. It is about a young man lost in thesea of started war, about his duty and honor. About funny as selectionist Gladyshev, successful, honest, naive, cruel people. About good and evil, the spiritual ideals and about one of the main human values - love. This, at first glance, strange, funny love softens drama ofgoing on, illuminates the real human faces with their fates, pains, joys. It becomes one hallmark that makes the director's conception in a bright, full, with a fine sense of humor, laughter through the tears performance with naturalistic rural life of the first days of war. In short, about those paradoxes, which has been mixed up lives of ordinary people, and that with a bit of humor so significantly been implementedon the stage.

Keywords: War; rear daily, human values, theater, performance, V. Voinovich, Russian Drama Theatre in Yakutia, directorial concept, Stage image, ordinary soldier big war.

\section{Введение}

В период радикального пересмотра мировоззрения начала 1990-х годов не могли не меняться культурные парадигмы. В этих условиях, чтобы всегда находиться на творческой волне, театр вынужден был отказаться от монистического взгляда на мир, а использовать метод жанрового разнообразия. Вот почему в репертуаре этого периода рядом с драмой соседствовала трагедия, мелодрама, комедия и даже водевиль. О процентном соотношении классики и современности уже речь не шла. Главной задачей было - удовлетворить разнообразные вкусы зрителей, привлечь их в театр. В какой-то мере это удалось с помощью
\end{abstract}


спектакля «Жизнь и необычайные приключения солдата Ивана Чонкина» по роману В.Войновича в инсценировке Л. Белявского.

Выбор не случаен. Во-первых, тем самым театр расширял свой репертуар. Во-вторых, через образы и, в частности, рядового Ивана Чонкина зрители смогли открыть для себя новые страницы военной тыловой повседневности, которая впервые была представлена на сцене. Заметим, что по реакции доперестроечных критиков, официальных пропагандистских кругов этот солдат-тыловик воспринимался вроде «бравого солдата Швейка, балагура Василия Теркина или сказочного Емели» [1]. Несмотря на то, что «Владимир Войнович писал "роман о любви", а не политическую сатиру, каковой принято было считать повествование о приключениях солдата Чонкина» [2],. тем не менее ответственные лица не находили ответа на многие вопросы. К примеру, каким образом маленький нелепый человек, рядовой солдат большой войны оказывается в центре событий, которые никак не соответствуют масштабам его личности? В связи с этим вставал вопрос: как воспринимать само произведение? Как сказку или фольклор? А Чонкина? Скорее всего, как народный архетип. А это значит, что и его, Чонкина, можно интерпретировать, видоизменять, использовать, как того же Иванушку Дурачка. Работая над романом, автор, действительно во многом опирался на фольклор и мифы, которые возникали вокруг армии и войны. Но это не повод относить его героя к разряду не серьезных людей. По его мнению «Чонкин не идиот, он обыкновенный простодушный человек, хотя немножко смахивает и на Швейка и Василия Теркина, и на сказочного русского солдата, который в огне не горит и в воде не тонет. Я его не задумывал, как идиота. Просто он оказывался в идиотских ситуациях, в которых нормальный человек вполне может стать идиотом. А это наши, обычные советские ситуации. Жизнь сама по себе сатирична - за ней просто нужно записывать. Как сказал один советский критик: “Вы придерживаетесь чуждой нам эстетики описания жизни, как она есть”» [1].

\section{Материалы и методы}

Источниковой базой послужил роман В.Войновича «Жизнь и необычайные приключения солдата Ивана Чонкина» инсценированный Л. Белявским и притворенный в сценический вариант режиссером А.Тарасовым, рецензии, публикации и отзывы на спектакль, а также воспоминания самого автора. Историко-театроведческий метод позволил воссоздать картину прошлого, отображенную на сценической площадке.

\section{Обсуждение}

Новый главный режиссер Анатолий Тарасов, в артисте Владимире Заманкове увидел «готового Чонкина»: «На него только шинель надеть». Конечно, этот посыл не был определяющим в выборе произведения, хотя и играл немаловажную роль. В большей степени эта работа интересовала постановщика и театр своей жизненной правдой, правдой войны и мира, правдой чести и бесчестия, правдой военной тыловой повседневности.

Режиссером «анекдотов в двух частях» стал сам инициатор, А. Тарасов. Оформила спектакль художник Лена Гоголева, Она создала оригинальный макет сценического самолета, часть Нюркиного огорода и ее коровы Красавки. Начинался спектакль с тех событий, когда в один из жарких июньских дней в селе Красное, что в трех сотнях шагов от речки со странным названием Тёпа, совершил вынужденную посадку самолет У-2, охранять который приказано рядовому Ивану Чонкину. Его любовь к деревенской почтальонше Нюрке Беляшовой, блестяще исполненной Татьяной Черниговской, стала тем лирическим лучом, который высвечивал путь к пониманию остальных персонажей.

Броско и свободно трактовал режиссер войновичевскую мысль. Перестроечный воздух свободы в виде лозунга вынес на сцену сокровенные мысли майора Фигурина о том, что «Советская власть настолько объективно хороша, что каждый, кому она не нравится полностью или частично является сумасшедшим». В то же время, спектакль не избежал сексуальной озабоченности героев. Полуистеричный вопль машинистки Капы (А. Антюхова), которая оправдывалась перед генералом Дрыновым (В. Ротин) о том, что у неё ни с кем ничего «не було», снижал ту доверчивость, открытость, которая виделась во взаимоотношениях Ивана и Нюры. В литературной основе нет акцента на европейский вопрос, и тем более не найти в нём упоминания о Гамсахурдиа и Ельцине. Тем не менее, 
современность заняла в спектакле свое место. Да и сам роман в инсценировке пережил трансформацию жанра - из романа-анекдота в трех частях он превратился в «двухчастные анекдоты», а вернее в траги-анекдоты. Потому что «нелепа сама ситуация, в которой оказывается главный герой. А несообразность и несоответствие между происходящими событиями и реакцией на них персонажей, усиливали его трагическое звучание» [3].

Такая трактовка действия режиссёром - не копия оригинала, а поиск своего решения произведения. Каждый творческий человек имеет на это право. Например, в одноименном фильме Чонкин вместе с Нюрой улетает на том самом самолете, который охранял. А «в Московском театре-студии на Усачевке под руководством Владимира Магара образ Чонкина был передан через шедевр советского монументального творчества - юного пионера с гордо вскинутой рукой, вечно салютующего “Всегда готов!” [4, с. 3-4]. Абсурд? В какой-то степени - да. Но такая интерпретация сценического образа рассматривалась как творческий метод, вытекающий из сути содержания произведения, которое в 1990-е и последующие годы было представлено не только на сценах России, но и Югославии, Германии, Эстонии, Латвии, Израиле. В 2009 г. впервые на Украине Чонкин вышел на подмостки Киевского Академического Театра драмы и комедии на Левом берегу Днепра в спектакле «Играем Чонкина», который поставили актеры Александр Кобзарь и Андрей Саминин. «Киевский спектакль получился не только смешным, но и очень зрелищным за счет того, что авторы инсценировки и режиссеры-постановщики сделали акцент на пластику и ввели элементы пантомимы, чем немало удивили первых зрителей» [5].

В Русском драматическом театре, как уже было сказано, роман тоже творчески «переосмыслили». В обстановку деревенского быта легко вписывалось живое исполнение русских народных песен, плясок. Это не только усиливало зрелищность спектакля, но и сглаживало его острые моменты. При этом не обошлись без некоторых потерь той художественной правды, которая заложена автором в романе. Но, так или иначе, спектакль получился и, прежде всего, благодаря достоверному слиянию с главным героем артиста Владимира Заманкова, а также удачным массовкам и «лаконичности сценографии».

Действительно, следя за Иваном Чонкиным, невольно приходишь к выводу: этот простодушный солдат - большая удача Заманкова, которая не так часто выпадает на актерскую долю. Слегка образованный, бесхитростно-наивный в отношениях с людьми, бесконечно преданный любви и долгу, честный до щепетильности его Чонкин вызывал безусловную зрительскую симпатию и выдерживал проверку в самых невероятных ситуациях при кажущейся внешней недалекости, непрактичности. Не случайно и вполне обоснованно председатель колхоза Голубев оценил его находчивость и организаторские способности по спасению колхозного урожая, дав ему следующую характеристику. «Ты, Ваня, человек очень умный. С виду дурак дураком, а приглядеться - ум государственный. Тебе бы не рядовым быть, а ротой командовать. А то и батальоном» [6]. По своей сути рядовой Чонкин из того же «теста», что и жители села Красное и составлял часть его народной культуры. Поэтому никак «не вписывался в облик войны. А если и оказывался причастным к ней, то только по необходимости - исполнить свой солдатский долг» [11].

Уже «шла третья неделя пребывания Чонкина в Красном, а из части, где он служил, не было ни слуху, ни духу. Никто не ехал, никто не летел, никто не давал указаний, как быть дальше» [6], что делать с самолетом. Трагизм в его положение, конечно, не со зла, а по бабьей недальновидности, внесла сама почтальонша Нюрка. Чтобы удержать его рядом, она просто напросто не отправляла в часть те письма, которые писал Чонкин, о чем солдат и не догадывался. Это и понятно. Надоело одиночество. Так хотелось опереться хоть на чье-то плечо. Не удивительно, что «с тех пор как в ее избе появился Иван, хозяйство постепенно стало приходить в порядок. И печь не дымит, и дверь закрывается, и коса отбита да наточена, даже такая ерунда, как, железяка, чтобы ноги от грязи у порога очищать, а и та, разве бы появилась без мужика? Вот и в один из дней Чонкин успел переделать кучу дел. Натаскал воду, наколол дров, накормил отрубями кабана Борьку и сварил обед для себя и для Нюры» [6]. Об этом он доложил ей, когда та вернулась с работы.

Да что там говорить, как ни как, а мужик - есть бабья опора. Иной раз так «глянет Нюра в окошко, задумается. Долго ли они живут вместе, а она к нему уже привязалась, сердцем присохла. А стоило ли? Не придется ли вскорости по живому-то отрывать? Неужели 
снова время придет такое, придешь домой, а дома четыре стены. Хоть с той говори, хоть с этой, она тебе не ответит. А тут вот хороший мужик, плохой ли, надолго ли, ненадолго, а всетаки свой. И приятно не только то, что он тебе по хозяйству поможет, а потом спать с тобой ляжет, приятно сознание того, что он есть» [6]. Так живут себе помаленьку, и ни Чонкин, ни Нюра, ни сельчане никакого представления не имеют о том, что 14 июня 1941 г. в ставке Гитлера состоялось совещание по окончательному уточнению последних деталей плана Барбаросса. В соответствии с ним «Германские вооруженные силы должны быть готовы разбить Советскую Россию в ходе кратковременной кампании еще до того, как будет закончена война против Англии» [7].

А если и случались, какие недоразумения, так по-своему и разрешали, безо всякого «суда и следствия». А все из-за чего. Этот Плечевой вроде бы и не со зла - «шутейно», чтонибудь да «бухнет», а у людей - «шекспирова трагедия». Вот и на этот раз. «А на что тебе обсматриваться? - говорит он как-то Чонкину. - Женись, да и все. У Нюрки все ж таки своя изба и своя корова. Да где ж ты еще такое найдешь? - Вообще-то верно, - соглашается тот. Вот я тебе и говорю, женись. Нюрка - баба очень хорошая, да, тебе про нее никто плохого не скажет. Она вон сколь ни жила одна, никогда ни с кем не путалась, и мужика у нее отродясь не было. Только с Борькой одним и жила, да. - С каким Борькой?» [6] - насторожился Иван, у которого от этой новости аж нижняя челюсть отвалилась.

Надо заметить, что новость Плечевого затронула не только простодушного Чонкина, особо не трудившегося над анализом услышанного, а принимавшего все на веру, но и зрителей, на которых тоже подействовал «эффект Плечевого». А все потому, что талант, произведенные действия и интонации двух актеров - Василия Саргина, исполнявшего Плечевого и Владимира Заманкова, выражение их лиц, взглядов, выдержанных пауз, движений не могли не произвести эффекта разорвавшейся бомбы. Зал, как и Чонкин, растерянно взирал на сцену, не зная, как относиться к только что услышанной новости. А это и есть тот необходимый «крючок» исполнителей, который нужен зрителям, чтобы «зацепиться» и вместе с ними переживать все происходящее на сцене, как свое личное. И это произошло.

Не успел Плечевой, довольный произведенным эффектом, не спеша удалиться с поля зрения, как Чонкин потребовал объяснений у Нюрки. «Я вот тебе дам шутейно!». Вначале решительно направлялся к двери, прихватив винтовку и вещмешок. «Ты чего это надумал? закричала она, заглядывая ему в глаза.- На что ты ружье берешь?» Хотела остановить и решительно закрывала собой входную дверь. «Пусти!» Чонкин попытался отодвинуть ее прикладом. «Говори, стерва, когда ты с ним снюхалась?» [6]

Несмотря на оскорбления Чонкина, Нюра продолжала отстаивать не только свое, но и достоинство, ставшего близким ей, человека. «Пусти!» - требовал Иван. Она словно прикипела к двери. Никакая сила не в состоянии была убрать ее с пути: «Не пущу!». И только когда Нюра убедилась, что напрасны все ее усилия, то уже не удерживала его. «Иди»,- сказала она, как отрезала.

В этот момент хрупкая внешность героини Т. Черниговской не сочеталась с ее внутренней стойкостью и той решительностью, с которой она оказывала сопротивление Чонкину. Как тут не вспомнить слова поэта: «Есть женщины в русских селеньях!...». Привыкшая к трудностям, она не искала защиты со стороны, а полагалась только на себя, на свои силы. Страшная, чудовищная шутка, а по сути дела навет, который возвел на неё Федька Решетов по прозвищу Плечевой о «сожительстве с боровом Борькой, Нюра восприняла с обидой, но с достоинством. «Ваня, ты это шутейно, да?» - еще раз переспросила она, пытаясь изобразить улыбку, глядя на Чонкина «ошалелым взглядом».

Она как бы пыталась понять, не сошел ли он с ума. А если нет, значит, она сумасшедшая, потому что ее бедный рассудок не мог охватить смысла того, что было здесь сказано, Подспудно она поняла, о чем идет речь, поняла степень унижения ее достоинства. Но вслух только и могла со стоном произнести: «Господи, что же это такое творится!». Нюрка выпустила из рук тряпку, которой мыла пол и, обхватив голову мокрыми руками, отошла к окну. Села на лавку не закричала, а тихо заплакала, вздрагивая всем телом. Заплакала беспомощно, как плачут больные дети, у которых не хватает сил плакать громко.

Зал затих в ожидании развязки Нюркиной трагедии. Новость буквально парализовала не только молодую женщину, что самым естественным образом передала актриса, но и 
зрителей. Такой реакции на свои слова Чонкин не ожидал. Он растерялся и, топчась у открытых дверей, не знал, как ему поступить. Потом прислонил винтовку к стене и подошел к Нюре. «Ты чё? Слышь, Нюрка! Я ведь не со зла, а с дуру. Мне Плечевой бухнул, а я не подумавши, тоже» [6], - оправдывался он.

Вот этой-то жалости и не вынесла душа одинокой женщины. Она не привыкла к ней, поэтому не перенесла его слов успокоения. Они произвели на нее обратное действие. Нюра закричала дурным голосом, упала на лавку, обхватила ее руками и стала давиться в рыданиях, вздрагивая всем телом. «Дурак я, слышь, Нюрка, дурак! Ну, ударь меня по голове хоть утюгом» [6]. Но та уже не слышала его слов. Чонкин продолжал суетиться около Нюрки. Прошло какое-то время и, собрав в кулак нервы, она постепенно начала успокаиваться и, наконец, затихла, только плечи ее продолжали вздрагивать. Чонкин принес ей воды. Нюра отхлебнула глоток и поставила ковшик на лавку перед собой. Потом села, утерла слезы воротником платья и спросила почти спокойно: «Исть будешь?

Несмотря на слезы, героиня Татьяны Черниговской не выглядела слабым существом. Просто это были слезы отчаяния и безысходности. Свою стойкость, мужество и самостоятельность она уже ни раз доказывала и докажет еще, когда вместе с Чонкиным будет защищать, охраняемый им самолет, «брать в плен» группу чекистов и с ружьем в руках удерживать их в своем доме. В то же время от нее нельзя было отнять ее совершенно трогательное наивное очарование. Своей открытостью, доверчивостью, доходившей до детской наивности, она продолжала удивлять зрителей даже тогда, когда ее уволили с работы за связь с «дизертиром», «нехорошим человеком» Чонкиным. Она не протестовала, а «всем показывала трудовую книжку и хвасталась»: «Уволили. За Чонкина. За Ивана. По любви, говорят, жила».

А сейчас немного успокоившись, Нюра стала собирать на стол. Потому, как это делала актриса, чувствовалось, что сносить незаслуженную обиду её героине приходится не впервой. Она привыкла к этому и понимает, пока рядом не будет мужика, хоть как веди она себя, хоть как блюди свое женское достоинство, все равно сплетен не миновать. Дальнейшими рассуждениями Черниговская глубже раскрывала нравственное состояние своей героини, к которым прислушивался весь зал. И была в них та пронзительная незатейливость, откровенность, которая по своему воздействию на чувства слушателей превосходила любую силу, любую угрозу. «Ты, Ваня, сам все решай, сам поступай, как знаешь, - начинала она печально и в то же время спокойно. - А Борьку я убивать не дам. С тобой я знакома без году неделя, а он у меня живет, почитай, уже два года» [6]. Она взяла его к себе, когда ему было всего три денечка. Сама молоком из бутылки через соску поила. Он ей стал вроде сына. Да и для него дороже Нюрки никого нет. И так прикипела она к своему «сыну Борьки», что иной момент сердце сжимается и от радости, и от печали. «Присяду я над этим Борькой и плачу как дура, сама не знаю, от радости или от горя, а скорее от того и другого» [6].

Внешне спокойные уверенные движения, только слегка «надтреснутый» от недавнего плача голос, выдавал волнения почтальонши. Вся она тут Нюра Беляшева. Вся душа нараспашку. «К тебе, Ваня, я хоть и привыкла и полюбила тебя, как мужика родного, но ты сегодня здесь, завтра там, найдешь себе другую, получше, да покрасивше, а для Борьки лучше меня никого нет. Все же живая душа. Если ты убьешь борова, думаешь, народ сразу престанет болтать? Да они же все от радости взвоют. А разговоров пойдет... Чего это он, мол, кабана вдруг стрелил? Понятно чего. С ним же Нюрка жила. А дальше больше. Один слово скажет, другой два прибавит. И уж так разрисуют, не хуже, чем в книге» [6].

Интеллект Чонкина был не в состоянии принять Нюрину философию. «Видать, Нюрка правду брешет про тебя Плечевой, - зло сказал солдат. - Либо я, либо кабан» [6]. Собрался и ушел к самолету. Лежа раздумывал о житье-бытье и о том, почему нет никаких дальнейших указаний насчет охраняемого «аэроплана». Уже сквозь дрему неожиданно для себя услышал, как диктор в громкоговорителе отчетливо выговаривал: «Германия так же неуклонно соблюдает условия советско-германского пакта о ненападении, как и Советский Союз, ввиду чего, по мнению советских кругов, слухи о намерениях Германии порвать пакт и предпринять нападение на Советский Союз лишены всякой почвы...» [6]. «Почва...», мелькнуло в его голове. Особенно если сдобренная нав...». Сон отключил сознание Чонкина. 
Несмотря на комизм ситуаций, действие разворачивалось на трагикомической волне. При этом каждый исполнитель вносил свою лепту в успех спектакля. Комичен был кладовщик, он же агроном-селекционер Гладышев в талантливом исполнении А. Кузнецова, который безуспешно выращивал знаменитый гибрид мирового значения - картофель с помидором «Путь к социализму» или сокращенно ПУКС.

Его опыты никак не могли увенчаться успехом, несмотря на «великие» страдания. Выходило все не то - вершки от картошки, корешки от помидоров. Его теория «круговорота навоза в природе» вызывала безудержный смех в зале. Как и «все гениальное», его эксклюзивный способ получения первача был предельно прост. Достаточно было взять «кило дерьма и смешать с кило сахара» - полученное зелье горело синим огнем. В чем и убедились сами зрители, глядя на наполненную комизмом сцену «визита» Чонкина к соседу - селекционеру.

Под стать ему жена Афродита, или по-деревенски Фроська - зачуханная, измотанная баба, уставшая вести борьбу с многочисленными горшочками мужа. Она и до замужества-то «не слыла красавицей, а сейчас и вовсе Бог знает, на что стала похожа» [6]. С появлением Афродиты «научным достижениям» Гладышева был нанесен значительный урон в виде разбитых горшков. За это «ученый муж» возненавидел свою вторую половину и называл не иначе как «змея гремучая». «А сколько я от нее, Ваня, горя натерпелся, это ни в сказке сказать, ни пером описать», - изливал свою душу Чонкину Гладышев.

Актриса Галина Кондрашова великолепно передала «беспросветную тоску» Афродиты по «безлабораторной жизни» в доме Гладышева. «Научные изыскания» мужа, как говорится, уже в печенках у нее и каждый горшочек с дерьмом острой болью отдавался в ее израненном сердце. Видимо, никаким светом своих «научных достижений» Гладышеву так и не удастся осветить потемки сознания жены. «Дура грязная, - в сердцах бросил селекционер. - У меня-то вонища с научной целью, а у нее в виде неряшества» [6].

Через несколько минут, взойдя на крыльцо, Чонкин мог сам убедиться в «змеином» характере Афродиты. На замечания мужа: «Хоть бы клеенку под дите подстелила, а то ведь напрудит - весь подол провоняет», - она_равнодушно огрызнулась: «Ты лучше в избе понюхай. И дай гостю понюхать» [6]. Вот и объясни после этого людям теорию «круговорота дерьма в природе» и его «пользы для человечества». Темнота некультурная. Не понимают того, что, к примеру, «французская фирма Коти из такого дерьма изготовляет духи тончайшего аромата», а они все носы зажимают.

Так за делами, да разговорами шло время, а Чонкина никто не менял. Никто не знал, что послу Германии в СССР Шуленбургу [8] была вручена нота, в которой говорилось: «несмотря на заключение Договора о ненападении между Германией и Советским Союзом, германские войска скапливаются у западных границ СССР. В связи с чем, советское правительство просило правительство Германии дать разъяснения по этому поводу» [9]. Этот документ был передан Гитлеру, когда до начала войны оставались минуты.

В тот день. Чонкин проснулся рано. Стояла полная непредсказуемая тишина. Стрелки часов показывали четыре часа. Он не ведал, что немцы уже бомбили Киев. Об этом все узнали спустя несколько часов, когда диктор объявил о начале войны. Это страшное слово повергло всех в шок - то ли верить, то ли нет. Сельчане, стали собираться у правления колхоза и прислушиваться к голосу из репродуктора, из которого доносились слова Молотова к : «Товарищам! Гражданам! Братьям и сестрам!» [10]. И это, столь доверительное обращение самым магическим образом действовало на собравшихся и на зрителей. Старшее поколение оно возвращало в то военное лихолетье, когда и стар, и млад, услышав это, а затем и обращение Сталина к «Гражданам и Гражданкам! Братьям и сестрам! Бойцам армии и флота!» уходил добровольцем на фронт, записывался в ополчение, становился на защиту Родины. Одни ценой своей жизни защищали ее, другие ковали победу в тылу, тем самым помогая фронту. Молодым важно было прикоснуться к истории своего Отечества. На примере хотя бы этого эпизода спектакля, когда беда объединяла народ одной целью, одним стремлением победить врага, приблизить прошлое, посмотреть на него своим взглядам, обратиться к своему сердцу, задуматься, почувствовать себя взрослым дать свою оценку. Спросить себя: «А как бы я поступил?», услышав весть о вероломном военном нападении агрессора в лице гитлеровской Германии тогда 22 июня ровно в четыре часа 1941 года. 
Всех одинаково потрясла эта новость, но каждый по-своему реагировал на нее. Кто-то побежал в магазин запасаться продуктами. Кто-то, как, например, Чонкин, несмотря на уговоры Нюрки, собирался на фронт: «Война уже идет, а я все тут..». Не дождавшись приказаний, выполняя уставной долг, он - винтовку в руки и уже ходил вокруг самолета, вертел головой, ожидая нападения Германии.

Перед собравшимися выступило районное руководство и бывшая доярка колхоза, а сейчас «официальное лицо» Люшка Мякишева в исполнении артистки Раисы Дорошенко. Ее героиня уже «прикоснулась» к цивилизации, поэтому в родную деревню приезжает только по особо важным делам. Родилась и выросла она в бедной семье. «Летом батрачила, зиму проводила безвылазно на печи, не имея ни валенок, ни штанов. В колхоз записалась одной из первой, доила бывших кулацких коров. Постепенно приобулась, приоделась, вышла замуж, вступила в партию» [6]. Газетное сообщение о новом методе доения коров за четыре соска одновременно подняло ударницу на такую недосягаемую для колхозников высоту, что сразу перечислить невозможно, сколько почетных званий, поручений, должностей возникло у нее. В родном колхозе появлялась только для того, чтобы перед фотоаппаратом или кинокамерой за соски корову дернуть. Последователей у Люшки Мякишевой оказалось столько, что возникло целое мякишевское движение. В Красное Люшка прибыла на «эмке». А этого не мог позволить себе даже первый секретарь райкома.

Перед сельчанами предстала крупная женщина в синем бостоновым костюме, белой блузке с орденом на левой груди. Короткая юбка плотно облегала объемные бедра ударницы, чем еще больше увеличивала ее размеры. В час, когда над страной нависла угроза, Люшка не могла молчать. Без промедления она обратилась к колхозникам с пламенной речью. «Бабы и мужики! Теперь, когда случилось такое несчастье, нам больше и делать ничего не остается, как сплотиться вокруг нашей родной партии, и лично вокруг товарища Сталина» [6]. Говорила она просто, доходчиво. Стоявшие перед ней сельчане то плакали, то улыбались сквозь слезы. «Труженики нашего хозяйства все силы отдадут...». Ударница несколько раз попеременно приложила платочек к глазам. «Все для фронта, все для победы!». Она немного помолчала, помедлила, собираясь с мыслями, и продолжила. «К вам, бабы, обращение особое. Не сегодня, завтра мужики наши, наши отцы...». Внезапно голос Люшки сорвался, но она проглотила подкативший комок к горлу. «Наши братья, наши мужья уйдут защищать свободу. Война есть война, может, и не кажному удастся вернуться». Женщины уже не сдерживали своих эмоций, то и дело утирали слезы, мужики застывшим взором смотрели куда-то в пространство. Туда же смотрел Чонкин и пока не видел ничего кроме охраняемого им самолета. «Но пока они будут там, мы здесь одни останемся. Трудно придется. И робята малые, и в избе надо прибрать, и сготовить, и постирать, и за своим огородом приглядеть, и о колхозном деле не забывать. Хотим мы того или нет, а теперича кажной за двоих, за троих придется работать. И за себя, и за мужиков» [6].

Актриса не стеснялась показаться на сцене некрасивой, малообразованной. Ради воплощения образа она готова пожертвовать и своей внешностью. Для нее важно было показать простую деревенскую женщину, озабоченную общим горем, общей целью спасения Родины. Ее Люшка то понижала, то повышала голос, временами замолкала собиралась с мыслями, обращалась то к сельчанкам, то к сельчанам. «И мы это должны выдюжить». «И выдюжим!» - переходя на более высокий регистр, махнув рукой, заверила она. «Мужики! Идите на фронт, выполняйте свой мужеский долг, защищайте нашу Родину от супостатов до последнего. А насчет нас не беспокойтесь. Мы вас заменим...»[6], - повысив голос, закончила бывшая доярка.

Остальные деревенские жители тоже не выглядели серой массой. Все они при полной самостоятельности, так или иначе «работали» на Ивана Чонкина. Тайка Горшкова и Нинка Курзова в исполнении В. Микулевич и М. Мигалкиной озорно пели частушки и лихо отплясывали пока не прогремела гроза, извещавшая войну. А как это случилось, то обе, соперничая друг с другом, стали вести борьбу за спички и мыло. Делали они это настолько профессионально, что в конце сезона актрисы были отмечены специальным призом

Весьма оригинален и комичен был В. Антонов в роли Некто. Как выяснилось, комизм положения его Моисея Соломоновича основывался на совпадении с фамилией Сталина. В один из воскресных дней он был задержан службой безопасности на колхозном рынке, 
где, торговал хромовыми голенищами. На вопрос, как его фамилия, человек этот сказал такое, что Климу Свинцову, отправленному на рынок для выяснения злостных распространителей ложных слухов, ничего не оставалось делать, как взять старого наглеца и отвести в особый отдел, именуемый Куда Надо. И только после того, когда там ему была выбита вставная челюсть, выяснилось, что эта фамилия действительно принадлежит ему. Потому что ее носил и дедушка, и его отец. Еще в царские времена дедушка имел небольшой заводик, где он варил сталь, поэтому его прозвали Сталин.

Несмотря на трагизм происходящего, не умолкал смех в зале во время допроса капитана Миляги (В. Шипулин) младшим лейтенантом Букашевым (В. Тверитин), который принял офицера особого отдела за немецкого разведчика. И «пленный», и лейтенант вели диалог на ломанном немецко-русском языке.

Герой В. Ротина - Дрынов скорее всего походил на пародию, чем на генерала. Его «беспринципность» и равнодушие к людям никак не вписывались в общий патриотический контекст военного времени. Тоже самое председатель колхоза Голубев в исполнении артиста Б. Чуднова, который вроде и хочет сделать что-то хорошее, да обстоятельства складываются не в его пользу. Органично вписался в спектакль, ведущий от лица автора М. Горбунов.

\section{Заключение}

До объявленной перестройки роман В.Войновича фактически был под запретом. Потому что своим отображением нелепой ситуацию, в которой оказывался главный герой, не «вписывался в концепцию социалистического реализма» [12]. С точки зрения нормальной человеческой логики невозможно оценить анекдотичность непредсказуемость происходящего, алогичность поступков и действий не только Чонкина, но и остальных персонажей. C одной стороны он стремится защищать Родину. В нем есть чувство ответственности. Он честно исполняет свой армейский долг и не покидает вверенный ему самолет. К тому же у него хватает мужества и смекалки не только отразить нападение спецслужб, но и взять их в плен, осознавая, свой поступок, как необходимость обезвредить врага. С другой - его без основания обвиняют в том, в чем он не виновен. Эта нелепость и алогичность особенно бросалась в глаза в сцене, когда генерал Дрынов награждал рядового Чонкина орденом за мужество и храбрость. Однако уже через несколько минут по ложному доносу объявлял его дезертиром, коим он в принципе никогда не был. Для любого нормального человека, оказавшегося в подобной ситуации это трагедия. Как известно, гибель героя в романе не акцентируется. У Войновича Чонкин уходит со словами утешения: «Не плачь, Нюрка! Я еще вернусь...». И это воспринимается, как вечность народного типа, страдающего от несправедливости, но бессмертного в своей жажде жизни.

В режиссерской концепции А.Тарасова Иван Чонкин становился жертвой интриги в духе современности. В то же время он единственный из персонажей, кто вызывал у зрителей не только улыбку, но и слезы. Особенно в последней сцене, когда его награждают, причем по заслугам и тут же объявляют врагом. Такого сожаления у зрителей не вызвала даже нелепость, случившаяся с капитаном Милягой. И, что характерно для Чонкина В. Заманкова. Он никогда не изменяет своим жизненным идеалам, своим внутренним убеждениям. Со всеми и всегда он предельно честен и открыт. В нем есть стойкость, но отсутствует агрессивность. Он весь домашний и заботы - все переделал, отремонтировал в доме, и интересы у него домашние - сидел бы у окна, да и вышивал крестиком. Несмотря на то, что все время попадает в ситуации не по своей воле, не теряет самообладания. В его стойкости и смекалке отражаются черты простого человека, не ищущего подвига, но совершающего его. И в этом живучесть данного народного образа не за славу, а за совесть защищавшего родное Отечество. Казалось бы, название спектакля и одноименного романа В.Войновича «Жизнь и необычайные приключения солдата Ивана Чонкина» не содержат в себе военной тематики. И только просмотрев его до конца убеждаешься в обратном. Все заботы Чонкина, все его мысли направлены на выполнение солдатского долга.

Поначалу модерновое прочтение прозы В. Войновича, не всеми воспринималось однозначно. Основная масса зрителей, воспитанная на классике и традиционных режиссерских решениях, привычных слуху и взору, не сразу разделила новации и поиск театра, навеянный ветром перемен. Это и понятно. Жизненные установки старшего 
поколения расходились с новыми политическими взглядами перестроечного времени, когда отрицались многие прежние идеалы и ценности. В этом смысле режиссер А.Тарасов и исполнители ролей, объединенные одной целью и одним стремлением, становились первопроходцами представления на сцене перестроечной тематики, направленной на смену политических и нравственных ориентиров. Помнится, Татьяна Черниговская вспоминала о том времени. «Спектакль складывался сразу, потому что Чонкин свой, “доморощенный”. С Володей Заманковым всегда легко работать. Он очень хороший партнер, гибкий, талантливый, добрый, интеллектуальный актер. Эти его качества всегда помогали и помогают на сцене». Его творческий союз с режиссером и другими актерами и создал сценический эффект «притяжения зрителя». Поэтому каждое последующее представление вызывало обоснованный интерес у зрительской аудитории. Он-то и показал, что театр не застывший, а развивающийся организм.

\section{Примечания:}

1. Войнович В. Проблематика [Электронный pecypc] URL: http://dic.academic.ru / dic.nsf/ruwiki/ 360134 (дата обращения 7.04.2015)

2. Бентя Ю. Комическое рядом. «КоммерсантЪ» 20.10.2009 [Электронный ресурс] URL: http:// www.drama-comedy.kiev.ua/ igraem-chenkina.html 14 (дата обращения 14.05.2015)

3. Журчева Т.В «Чонкин» на Самарскиой сцене (Проблемы интерпретации) [Электронный pecypc] URL: http://netrover.narod.ru/lit3wave/3_4.htm (дата обращения 14.05.2015)

4. Антонов 3. Люди и лошади // Театральная жизнь, 1991. № 8.

5. Куйбина Л. Чё, чё... Чонкин! //«Известия в Украине» 9.10.2009 [Электронный pecypc] URL: http://www.drama-comedy.kiev.ua/igraem-chenkina.html (дата обращения 14.05.2015)

6. Войнович В. Жизнь и необычайные приключения солдата Ивана Чонкина. [Электронный pecypc] URL: http://fanread.ru/book/3591532/?page=1 (дата обращения 7 04.2015)

7. План Барбаросса. //Оглашению подлежит. СССР - Германия 1939-1941. Документы и материалы - Ю. Фельштинский [Электронный ресурc] URL: http://xn-80aatn3b3a4e.xn--p1ai/book/729o/297757/144 (дата обращения 14.05.2015)

8. Риббентроп -- Послу Шуленбургу //Оглашению подлежит. СССР - Германия 1939-1941. Документы и материалы - Ю. Фельштинский [Электронный ресурс] URL: http://xn--80aatn3b3a4e.xn--plai/ book/ 7290/297802/177. (дата обращения 14.05.2015)

9. Договор о ненападении между Германией и Советским Союзом. //Оглашению подлежит. СССР - Германия 1939-1941. Документы и материалы - Ю. Фельштинский [Электронный pecypc] URL: // http://xn--80aatn3b3a4e.xn-plai/ book/ 7290/297594/ (дата обращения 14.05.2015)

10. Из выступления по радио В. М. Молотова. 22 июня 1941 года. //Оглашению подлежит. СССР - Германия 1939-1941. Документы и материалы - Ю. Фельштинский [Электронный pecypc] URL: http://xn--80aatn3b3a4e.xn-plai/ book/ 7290/297808/ (дата обращения 14.05.2015)

11. Тишина Т. О Чонкине бедном замолвите слово // Социалистическая Якутия, 1972, 5 март.

12. Blake Patricia. Breaking Through in Fiction //Time. 1980. Jun., 23. Monday. [Электронный pecypc] URL: http:// content.time.com/time/magazine/article/ 0,9171,9220523,00.html (дата обращения 14.05.2015)

\section{Referenses}

1. Voynovich V. Problematika. Available at: http://dic.academic.ru/dic.nsf/ruwiki / 360134 (Accessed 7 April 2015).

2. Bentya Yu. Komicheskoe ryadom. Komersant 20. Oktouber 10.2009 Available at: http:// www.drama-comedy.kiev.ua/ igraem-chenkina.html (Accessed 14. May 2015)

3. Zhurcheva T.V. "Chonkin" na Samarskoy stsene (Problemy interpritatsyi) Available at: http:// netrover.narod.ru/lit3wave/3_4.htm (Accessed 14 May 2015).

4. $\quad$ Antonov Z. Lyudi I loshadi Teatralnaya Zhizn', 1991. No. 8. 
5. Kuybina L. Che, Che... Chonkin! "Tzvestiya v Ukraine” 9.October 10.2009. Available at: http:// www.drama-comedy.kiev.ua/ igraem-chenkina.html (Accessed 14 May 2015).

6. Voynovich V. Zhizn' i neobychaynye priklyucheniya soldata Ivana Ychonkina. Available at: http:/ / fanread.ru/ book/ 3591532/ ?page=1 (Accessed 7 April 2015).

7. Plan Barbarossa. Oglasheniyu podlezhit. SSSR - Germaniya 1939-1941. Dokumenty i materialy - Yu. Fel'shtinskiy Available at http://xn--80aatn3b3a4e.xn-plai/ book/ 7290/ 297757/ 144 (Accessed 14 May 2015).

8. Ribbentrop -- Poslu Shulenburgu Oglasheniyu podlezhit. SSSR - Germaniya 1939-1941. Dokumenty i materialy - Yu. Fel'shtinskiy. Available at. http://xn--80aatn3b3a4e.xn-p1ai/ book/ 7290/ 297802/ 177. (Accessed 14 May 2015).

9. Dogovor o nenapadenii mezhdu Germaniey i Sovetskim Souzom Oglasheniyu podlezhit. SSSR - Germaniya 1939-1941. Dokumenty i materialy - Yu. Fel'shtinskiy Available at. http://xn--80aatn3b3a4e.xn--plai/ book/ 7290/297594/ (Accessed 14 May 2015).

10. Iz vystupleniya po radio V. M. Molotova. 22 J uny 1941 goda. Oglasheniyu podlezhit. SSSR - Germaniya 1939-1941. Dokumenty i materialy - Yu. Fel'shtinskiy. Available at: http://xn-80aatn3b3a4e.xn--p1ai/ book/ 7290/297808/ (Accessed 14 May 2015). 1972.

11. Tishina T. O Chonkine bednom zamolvite slovo Sotsialisticheskaya Ykutiya, 5 March

12. Blake Patricia. Breaking Through in Fiction //Time. 1980. J un., 23. Monday. Available at: http://content.time.com/time/magazine/article/0,9171,922052-3,00.html (Accessed 14 May 2015).

УДК 292.09: 94(470)

\section{«Война уже идет, а я все тут...» \\ или картина военной тыловой повседневности глазами современного театра}

Вера Климентьевна Крылова

Институт гуманитарных исследований и проблем малочисленных народов Севера

Сибирского отделения Российской академии наук, Российская Федерация

677027, Якутск, Петровского, 1

Кандидат искусствоведения, старший научный сотрудник

E-mail: kvkrepressgur@mail.ru

Аннотация. В статье дается анализ спектакля «Жизнь и необычайные приключения солдата Ивана Чонкина» по одноименному роману Владимира Войновича, поставленного Академическим Русским драматическим театром в Якутии. Этот спектакль не только о Чонкине. Он о маленьком человеке, затерявшемся в море начавшейся войны, его долге и чести. О смешных, как селекционер Гладышев, удачливых, честных, наивных, жестоких людях. О добре и зле, о духовных идеалах и об одной из главных человеческих ценностей любви. Эта, на первый взгляд, странная, смешная любовь смягчает драматизм происходящего, озаряет подлинные человеческие лица со своими судьбами, болями, радостями. Она и становится той отличительной чертой, которая превращает режиссерскую концепцию в яркий, насыщенный, с тонким юмором, смехом сквозь слезы спектакль с натуралистическим деревенским бытом первых дней войны. Словом, о тех парадоксах, на которых была замешана жизнь простого люда, и которые с долей юмора так достоверно были воплощены на сцене.

Ключевые слова: война, тыловая повседневность, человеческие ценности, театр, спектакль, В.Войнович, Русский драматический театр в Якутии, режиссерская концепция, сценический образ, рядовой солдат большой войны. 